\title{
Klasifikasi Lama Studi dan Predikat Kelulusan Mahasiswa menggunakan Metode Naïve Bayes
}

\author{
I Nyoman Rudy Hendrawan', I Made Arya Budhi Saputra ${ }^{2}$, Gusti Ayu Putu Cahya Dewi ${ }^{3}$, I Gede \\ Surya Adi Pranata ${ }^{4}$, Ni Luh Nyoman Wedasari ${ }^{5}$ \\ Program Studi Sistem Informasi \\ Institut Teknologi dan Bisnis STIKOM Bali \\ Denpasar, Indonesia \\ e-mail: ${ }^{1}$ rudyhendrawan@ stikom-bali.ac.id, ${ }^{2}$ aryabudhi@stikom-bali.ac.id, ${ }^{3}$ cahyadewi908@gmail.com, \\ ${ }^{4}$ spranata55@gmail.com, ${ }^{5}$ weda@ $@$ stikom-bali.ac.id \\ Diajukan: 27 Agustus 2021; Direvisi: 27 September 2021; Diterima: 30 September 2021
}

\begin{abstract}
Abstrak
Ketepatan waktu studi mahasiswa adalah hal yang penting dalam perguruan tinggi. Ketepatan waktu mahasiswa dalam menyelesaikan studi menjadi salah satu penunjang penilaian kualitas perguruan tinggi. Hal ini tentu saja berpengaruh terhadap mutu kelulusan mahasiswa dan predikat kelulusan pada mahasiswa itu sendiri terutama pada saat proses akreditasi. Oleh karena itu, pada penelitian ini diklasifikasikan lama studi dan predikat kelulusan mahasiswa dengan tujuan untuk membantu pihak program studi dan fakultas dalam menganalisis luaran pembelajaran. Metode klasifikasi yang diterapkan pada penelitian ini adalah Nä̈ve Bayes. Data yang digunakan adalah data mahasiswa Institut Teknologi dan Bisnis STIKOM Bali tahun 2008 sampai dengan tahun 2016 dengan total jumlah data sebanyak 5.081. Atribut dataset yang digunakan untuk mengklasifikasikan Lama Studi dan Predikat Kelulusan adalah Jenis Kelamin, Prodi, Konsentrasi, Tahun Masuk, dan Tahun Lulus. Hasil eksperimen menunjukkan bahwa akurasi tes classifier untuk klasifikasi lama studi sebesar 0,74 dan untuk akurasi tes klasifikasi predikat kelulusan sebesar 0,61 pada kelompok data Program Studi Sistem Komputer. Kemudian untuk kelompok data Program Studi Sistem Informasi akurasi tes klasifikasi lama studi sebesar 0,73 dan untuk akurasi klasifikasi predikat kelulusan sebesar 0,67.
\end{abstract}

Kata kunci: Klasifikasi, Lama studi, Predikat kelulusan, Nä̈ve Bayes.

\begin{abstract}
Length of study is important at the university level. The punctuality of students in completing their studies is one of the supporting factors for evaluating the quality of higher education. This of course affects the quality of student graduation and the graduation predicate on the students themselves, especially during the accreditation process. Therefore, in this study, study period and the graduate honor of students were classified in regard to assisting faculty in analyzing the learning outcomes. Institut Teknologi dan Bisnis STIKOM Bali students' data is used from 2008 to 2016 with a total of 5.081 data. The dataset attributes that used to classify study period dan graduation honor are gender, concentration, and year of admission. The experimental results show that the classifier test accuracy of study period is 0.74 and the classification test accuracy of the graduate honor is 0.61 in the data group of the Computer Systems study program. Then for the data group of the Information Systems study program, the classification test accuracy of study period is 0.73 , and for the classification test accuracy of the graduate honor is 0.67 .
\end{abstract}

Keywords: Classification, Study period, Graduate honor, Nä̈ve Bayes.

\section{Pendahuluan}

Institut Teknologi dan Bisnis STIKOM Bali adalah salah satu perguruan tinggi swasta di Bali yang memiliki dua program studi yaitu program studi sarjana Sistem Informasi dan Sistem Komputer. Lama masa studi yang ditempuh oleh mahasiswa merupakan salah satu standar yang termasuk ke dalam standar penilaian pada Standar Nasional Pendidikan Tinggi atau SN-DIKTI, masa studi untuk program sarjana maksimal tujuh tahun akademik dengan beban belajar mahasiswa paling sedikit 144 SKS. Mahasiswa harus berjuang melewati lebih dari 100 SKS dengan ketentuan IPK minimal 2.00 [1]. 
Seperti dalam buku Pedoman Pendidikan Tahun 2014-2015 (STIKOM Bali) evaluasi hasil studi pada akhir jenjang studi Strata 1 (S-1) menyebutkan bahwa mahasiswa yang mencapai Indeks Predikat Kumulatif (IPK) minimal 2,00, tidak ada nilai E. Artinya bahwa mahasiswa bisa menempuh perkuliahan hanya dengan 3,5 tahun bila mencapai syarat yang telah ditentukan. Salah satu permasalahan yang sering terjadi di perguruan tinggi khususnya Institut Teknologi dan Bisnis STIKOM Bali yaitu ketidakseimbangan antara mahasiswa yang masuk dan lulus. Mahasiswa yang masuk dalam jumlah banyak, namun jumlah yang lulus tepat waktu jauh lebih sedikit dari pada mahasiswa yang masuk ke Institut Teknologi dan Bisnis STIKOM Bali yang akan berpengaruh terhadap mutu mahasiswa dan predikat kelulusan pada mahasiswa itu sendiri. Data ini dapat dijadikan sebuah informasi yang berharga dalam pengambilan keputusan dengan menganalisis informasi yang ada, maka untuk membantu dalam menemukan informasi berharga itu diperlukan teknik data mining. Pada dasarnya data mining berhubungan erat dengan analisa data dan penggunaan perangkat lunak untuk mencari pola dan kesamaan dalam pengumpulan data [2]. Beberapa teknik atau algoritma dalam data mining, salah satunya adalah Naïve Bayes. Kelebihan dari algoritma Naïve Bayes yaitu relatif mudah untuk diimplementasikan karena tidak menggunakan optimasi numerik, perhitungan matriks dan lainnya, efisien dalam pelatihannya dan penggunaannya, bisa menggunakan data binary atau polinom karena diasumsikan independen maka memungkinkan metode ini diimplementasikan dengan berbagai macam dataset [2].

Penelitian oleh [3], menggunakan metode Naïve Bayes untuk memprediksi peluang kelulusan mahasiswa baru pada suatu perguruan tinggi. Hasil evaluasi klasifikasi menunjukkan bahwa Naïve Bayes menghasilkan keakuratan prediksi sebesar 93,6\%. Penelitian lainnya oleh [4], menggunakan metode yang sama untuk mengklasifikasikan kelulusan mahasiswa di Universitas Dian Nuswantoro. Serupa dengan penelitian oleh [4], penelitian oleh [5]-[9] juga menggunakan metode Naïve Bayes untuk memprediksi kelulusan mahasiswa. Berdasarkan penelitian-penelitian tersebut didapatkan bahwa Naïve Bayes memiliki kemampuan yang cukup baik dalam memprediksi kelulusan mahasiswa dengan tingkat akurasi dari $68 \%$ hingga $80 \%$.

Pada penelitian ini dilakukan suatu analisa dan prediksi untuk menentukan lama masa studi dan predikat kelulusan yang didapat dari data mahasiswa Institut Teknologi dan Bisnis STIKOM Bali menggunakan metode Naïve Bayes. Untuk data yang digunakan sebagai keperluan penelitian adalah data mahasiswa dari angkatan 2008-2016, menggunakan parameter antara lain jenis kelamin, program studi, konsentrasi, tahun masuk, dan tahun lulus. Penelitian yang dilakukan diharapkan membantu pihak program studi dan fakultas dalam menganalisis luaran pembelajaran.

\section{Metode Penelitian}

\subsection{Tipe Atribut}

Metode yang digunakan dalam penelitian ini adalah metode penelitian eksperimen, yang ditunjukkan pada Gambar 1. Data yang digunakan adalah dataset mahasiswa Institut Teknologi dan Bisnis STIKOM Bali dari tahun angkatan 2008 sampai dengan tahun angkatan 2016, total jumlah dataset ini sebanyak 5.081 data mahasiswa. Jumlah keseluruhan kolom pada dataset ini sebanyak sepuluh kolom di antaranya, Nomor Induk Mahasiswa (NIM), nama mahasiswa, jenis kelamin, program studi, konsentrasi, tahun masuk, tahun lulus, lama studi (dalam tahun), predikat kelulusan, dan keterangan kelulusan. Namun, untuk melakukan klasifikasi atribut NIM, nama mahasiswa, dan program studi tidak diikutsertakan, sedangkan kolom predikat kelulusan dan keterangan kelulusan digunakan sebagai label data.

Atribut dataset yang digunakan untuk mengklasifikasikan Lama Studi dan Predikat Kelulusan adalah Jenis Kelamin, Prodi, Konsentrasi, Tahun Masuk, dan Tahun Lulus. Kelas Lama Studi dikategorikan berdasarkan tahun lulus yang ditempuh untuk mencapai kelulusan yaitu, Tepat Waktu, jika lama studi delapan semester atau kurang dari delapan semester. Kemudian dikategorikan Terlambat, jika lama studi lebih dari delapan semester. Kelas predikat kelulusan ditentukan berdasarkan IPK yang dibagi menjadi tiga bagian yaitu, Memuaskan, jika IPK antara 2,00 dan 2,75; Sangat Memuaskan, jika IPK antara 2,76 dan 3,50; dan Cumlaude, jika IPK antara 3,51 dan 4,0. Tabel 1 menunjukkan detail atribut dataset mahasiswa yang digunakan untuk proses klasifikasi.

Tabel 1. Atribut data mahasiswa.

\begin{tabular}{ccc}
\hline Atribut & Tipe Atribut & Keterangan \\
\hline Jenis Kelamin & Kategori & Jenis kelamin mahasiswa \\
\hline Prodi & Kategori & Program Studi mahasiswa \\
\hline Konsentrasi & Kategori & Konsentrasi mahasiswa \\
\hline Tahun Masuk & Kategori & Tahun masuk mahasiswa \\
\hline Tahun Lulus & Kategori & Tahun lulus mahasiswa \\
\hline
\end{tabular}

Klasifikasi Lama Studi dan Predikat Kelulusan Mahasiswa menggunakan Metode Nä̈ve Bayes (I Nyoman Rudy Hendrawan) 


\subsection{Eksplorasi Data}

Berikut adalah contoh dataset yang diambil secara acak, Tabel 2 adalah dataset yang digunakan untuk klasifikasi Lama Studi dan Tabel 3 digunakan untuk klasifikasi Predikat Kelulusan. Proses klasifikasi pada penelitian ini menggunakan bantuan perangkat lunak Orange. Gambar 2 menunjukkan alur kerja perangkat lunak Orange dalam proses klasifikasi hingga proses evaluasi.

\subsection{Pembagian Data}

Proses klasifikasi dibagi menjadi dua kategori berdasarkan program studi mahasiswa, yaitu Program Studi Sistem Komputer dan Sistem Informasi, sehingga jumlah data untuk masing-masing program studi adalah sebanyak 2.813 dan 2.246 baris data. Setiap kelompok dataset tersebut dibagi menjadi train set dan test set dengan proporsi sebesar $80 \%$ dan $20 \%$ secara berturut-turut. Berikut Tabel 4 rincian pembagian data train set dan test set.

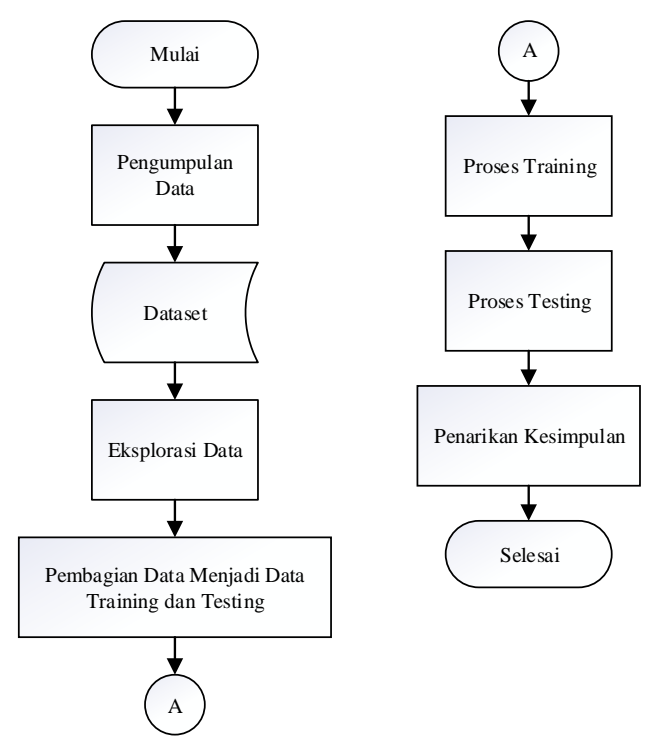

Gambar 1. Flowchart alur penelitian.

Pada dataset kelompok Program Studi Sistem Komputer dan Sistem Informasi terdapat missing value sebanyak 486 dan 2 secara berturut-turut pada atribut data Konsentrasi. Untuk mengatasi permasalahan pada jumlah missing value yang cukup banyak (sebesar $17 \%$ data) di dataset kelompok Program Studi Sistem Komputer dilakukan dengan cara mengganti nilai tersebut dengan nilai random [10], sedangkan pada Program Studi Sistem Informasi dilakukan penghapusan record data dikarenakan jumlahnya jauh lebih sedikit [10].

Tabel 2. Contoh dataset mahasiswa kelas lama studi.

\begin{tabular}{cccccc}
\hline Jenis Kelamin & Prodi & Konsentrasi & Tahun Masuk & Tahun Lulus & Lama Studi \\
\hline L & SK & Networking and Cyber Security & 2010 & $2015 / 2016$ & Terlambat \\
\hline P & SI & Enterprise System & 2010 & $2015 / 2016$ & Terlambat \\
\hline L & SK & Robotic and Embedded System & 2010 & $2013 / 2014$ & Tepat \\
\hline
\end{tabular}

Tabel 3. Contoh dataset mahasiswa kelas predikat kelulusan.

\begin{tabular}{cccccc}
\hline Jenis Kelamin & Prodi & Konsentrasi & Tahun Masuk & Tahun Lulus & Predikat kelulusan \\
\hline P & SI & Intelligence System & 2010 & $2013 / 2014$ & Cumlaude \\
\hline L & SI & Intelligence System & 2010 & $2014 / 2015$ & Sangat Memuaskan \\
\hline L & SK & Robotic and Embeded System & 2010 & $2014 / 2015$ & Sangat Memuaskan \\
\hline
\end{tabular}




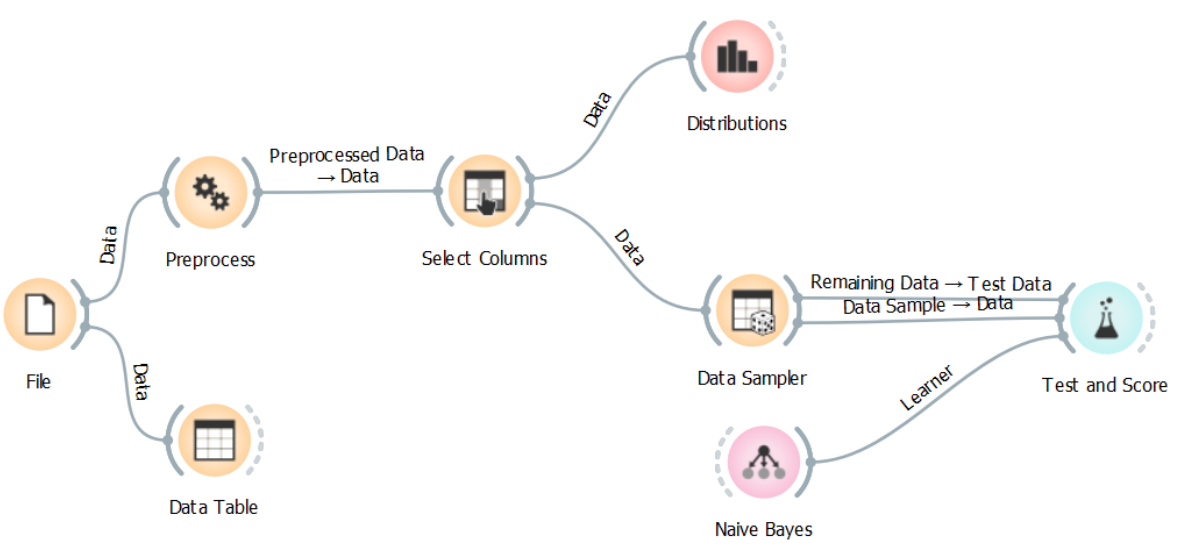

Gambar 2. Alur kerja perangkat lunak Orange.

Tabel 4. Rincian pembagian data.

\begin{tabular}{lcc}
\hline \multirow{2}{*}{ Kelompok Data } & Jumlah Train Set & Jumlah Test Set \\
\cline { 2 - 3 } & $\mathbf{8 0 \%}$ & $\mathbf{2 0 \%}$ \\
\hline Program Studi Sistem Komputer & 2250 & 563 \\
\hline Program Studi Sistem Informasi & 1796 & 449 \\
\hline
\end{tabular}

Berdasarkan alur kerja (Gambar 2) di atas terdapat widget yang digunakan antara lain dapat dilihat pada Tabel 5 di bawah ini:

Tabel 5. Widget pada Orange.

\begin{tabular}{cl}
\hline Widget & \multicolumn{1}{c}{ Keterangan } \\
\hline File & Digunakan untuk menentukan atribut yang digunakan pada label lama studi dan predikat kelulusan. \\
\hline Preprocess & Digunakan untuk melakukan proses preprocessing. \\
\hline Data Table & Digunakan untuk menampilkan data dalam tabel. \\
\hline Select Column & Digunakan untuk menentukan target atau kelas data. \\
\hline Distributions & Digunakan untuk menampilkan visualisasi data dalam bentuk histogram. \\
\hline Data Sampler & Digunakan untuk mengatur proporsi pada train set dan test set. \\
\hline Test and Score & Digunakan untuk menampilkan hasil pengujian berdasarkan parameter Area Under the Curve, Classifier \\
& Accuracy $(C A), F 1$ Score, Precission, dan Recall \\
\hline Nä̈ve Bayes & Metode Naïve bayes yang diimplementasikan \\
\hline ROC Analysis & Digunakan untuk menampilkan kurva Receiver Operating Characteristic (ROC)
\end{tabular}

Pengujian dilakukan berdasarkan metrik Area Under the Curve (AUC), Akurasi (CA), F1, Precision dan Recall melalui perangkat lunak Orange. Berikut penjelasan mengenai metrik pengujian yang digunakan:

1. AUC adalah suatu daerah di bawah ROC. ROC merupakan kurva yang dihasilkan dari tarik ulur antara sensitivitas dan spesifisitas pada berbagai titik potong. Semakin besar area under curve maka semakin baik variabel yang diteliti dalam memprediksi kejadian.

2. Akurasi (CA) merupakan ukuran kinerja yang paling intuitif dan ini hanya rasio pengamatan yang diprediksi dengan benar terhadap total pengamatan.

3. F1 adalah penggabungan Recall dan Precission ke satu metrik kinerja. Skor F1 adalah ratarata dari Precission and Recall. Oleh karena itu, skor ini memperhitungkan prediksi dengan nilai positif dan prediksi dengan nilai negatif.

4. Precission merupakan rasio pengamatan positif yang diprediksi dengan benar dengan total pengamatan positif yang diprediksi.

5. Recall menunjukkan rasio prediksi benar positif dibandingkan dengan keseluruhan data yang benar positif.

\section{Hasil dan Pembahasan}

\subsection{Hasil}

Pada bagian ini disajikan hasil klasifikasi kelas Lama Studi pada kategori data Program Studi Sistem Komputer dan Sistem Informasi. Hasil klasifikasi ini (Tabel 6 dan Tabel 7) berdasarkan lima metrik 
pengukuran yang telah dijelaskan pada bagian sebelumnya, setiap tabel di bawah ini adalah hasil pengukuran metrik pada train set dan test set.

Tabel 6. Hasil pengukuran pada kategori Program Studi Sistem Komputer.

\begin{tabular}{ccccccc}
\hline Kelas & Data & AUC & CA & F1 & Precision & Recall \\
\hline Lama Studi & Train & 0,78 & 0,74 & 0,76 & 0,78 & 0,74 \\
\cline { 2 - 7 } & Test & 0,78 & 0,74 & 0,75 & 0,78 & 0,73 \\
\hline \multirow{2}{*}{ Predikat Kelulusan } & Train & 0,65 & 0,64 & 0,57 & 0,52 & 0,64 \\
\cline { 2 - 7 } & Test & 0,62 & 0,61 & 0,54 & 0,49 & 0,61 \\
\hline
\end{tabular}

Tabel 7. Hasil pengukuran pada kategori Program Studi Sistem Informasi.

\begin{tabular}{ccccccc}
\hline Kelas & Data & AUC & CA & F1 & Precision & Recall \\
\hline \multirow{2}{*}{ Lama Studi } & Train & 0,81 & 0,73 & 0,73 & 0,74 & 0,73 \\
\cline { 2 - 7 } & Test & 0,81 & 0,73 & 0,73 & 0,74 & 0,73 \\
\hline \multirow{2}{*}{ Predikat Kelulusan } & Train & 0,68 & 0,66 & 0,64 & 0,62 & 0,66 \\
\cline { 2 - 7 } & Test & 0,65 & 0,67 & 0,65 & 0,64 & 0,67 \\
\hline
\end{tabular}

Pada Gambar 3, terlihat grafik perbandingan hasil training dan testing di semua metrik pengukuran. Tabel 6 dan Tabel 7 juga memperjelas hasil pengukuran tersebut di mana hasil pengukuran training dan testing tidak jauh berbeda, bahkan jika dilihat secara keseluruhan hasil training dan testing cenderung menunjukkan hasil yang sama. Namun, jika dilihat dari perbandingan antar kelas pada masingmasing kelompok data, terdapat perbedaan pada hasil pengukuran. Berdasarkan kelima metrik pengukuran, kelas Lama Studi memiliki hasil pengukuran yang lebih baik daripada kelas Predikat Kelulusan. Hal ini dapat dilihat pada Tabel 6 dan Tabel 7, di mana nilai metrik pada kelas Predikat Kelulusan tidak ada yang mencapai nilai 0,7 .

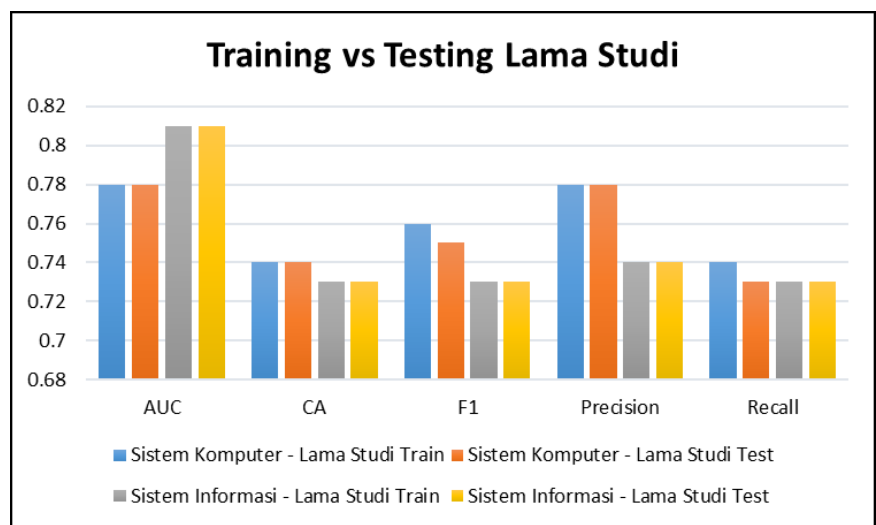

Gambar 3. Grafik hasil training dan testing pada kelas lama studi.

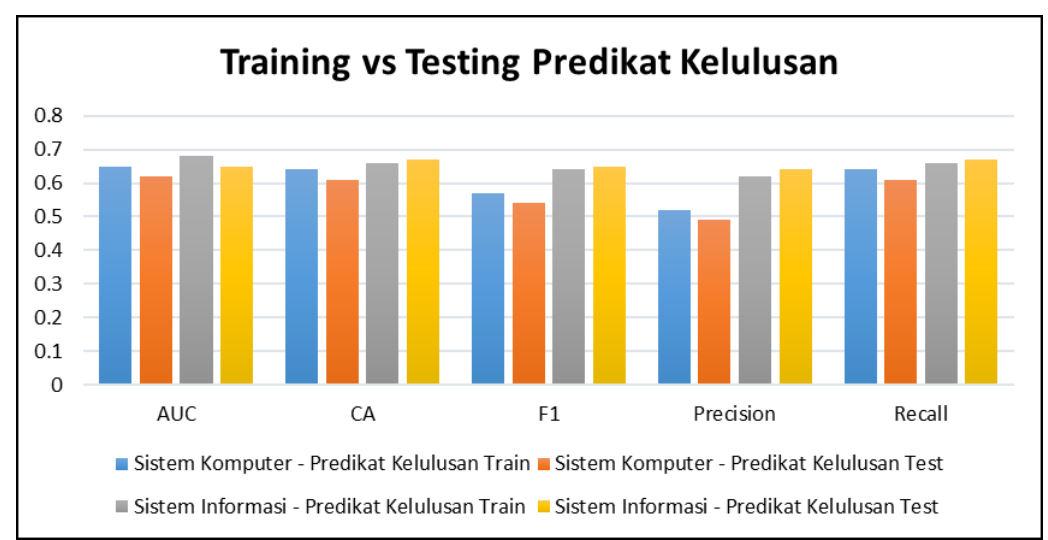

Gambar 4. Grafik hasil training dan testing pada kelas lama studi. 


\subsection{Pembahasan}

Seperti yang telah dijelaskan pada bagian sebelumnya di mana kinerja classifier Naïve Bayes tidak cukup baik pada kelas Predikat Kelulusan baik itu dari kelompok data Program Studi Sistem Komputer ataupun Program Studi Sistem Informasi. Berdasarkan studi literatur yang dilakukan [11][12][13], didapatkan bahwa salah satu penyebab dari permasalahan ini adalah adanya ketidakseimbangan (pada bagian selanjutnya digunakan istilah imbalanced) data pada nilai kelas yang diklasifikasikan, yaitu Predikat Kelulusan. Gambar 5 memperjelas permasalahan imbalanced ini, di mana ada ketidakseimbangan antara nilai Cumlaude, Memuaskan, dan Sangat Memuaskan. Jumlah data dengan nilai Sangat Memuaskan jauh lebih banyak daripada nilai Memuaskan dan juga Cumlaude.

Imbalanced pada data menyebabkan adanya kelas mayoritas dan juga minoritas. Hal ini tentu saja bermasalah karena classifier akan cenderung lebih banyak belajar pada pola data mayoritas daripada yang minoritas, sehingga keputusan yang dihasilkan oleh classifier akan menjadi bias, sehingga metrik CA tidak dapat lagi digunakan sebagai satu-satunya metrik yang digunakan sebagai penentu kinerja classifier [14]. Berdasarkan [12], terdapat beberapa teknik pendekatan yang dapat dilakukan untuk mengatasi permasalahan imbalanced data seperti pada penelitian ini, pertama berdasarkan pendekatan dekomposisi, yaitu mengubah permasalahan multi-class menjadi binary-class. Kedua, pendekatan ad-hoc, yaitu pendekatan untuk mengatasi masalah imbalanced mulai dari proses preprocessing sampai dengan proses klasifikasinya. Namun untuk kedua teknik pendekatan tersebut di luar dari lingkup penelitian ini sehingga tidak dapat dijelaskan lebih lanjut dengan hasil penelitian.

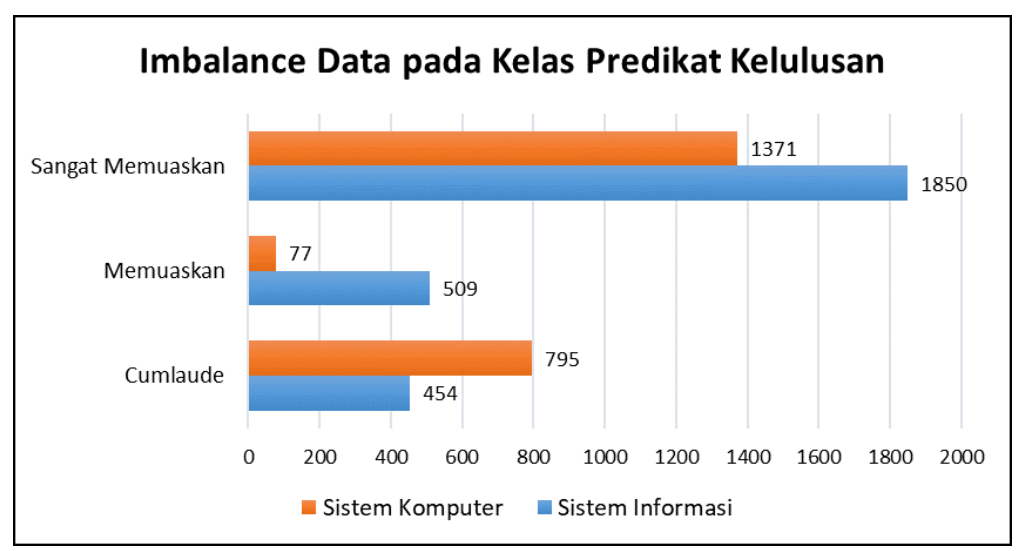

Gambar 5. Imbalanced data pada kelas predikat kelulusan.

\section{Kesimpulan}

Berdasarkan hasil penelitian maka didapat kesimpulan sebagai berikut:

1. Perbandingan hasil training dan testing di semua metrik pengukuran. menunjukkan bahwa hasil pengukuran training dan testing tidak jauh berbeda, bahkan jika dilihat secara keseluruhan hasil training dan testing cenderung menunjukkan hasil yang sama.

2. Jika dilihat dari perbandingan antar kelas pada masing-masing kelompok data, terdapat perbedaan pada hasil pengukuran. Berdasarkan kelima metrik pengukuran, kelas Lama Studi memiliki hasil pengukuran yang lebih baik daripada kelas Predikat Kelulusan, di mana nilai metrik pada kelas Predikat Kelulusan tidak ada yang mencapai nilai 0,7.

3. Kinerja classifier Naïve Bayes tidak cukup baik pada kelas Predikat Kelulusan baik itu dari kelompok data Program Studi Sistem Komputer ataupun Program Studi Sistem Informasi, hal ini dikarenakan adanya imbalanced data.

4. Imbalanced pada data menyebabkan adanya kelas mayoritas dan juga minoritas, hal ini menyebabkan classifier cenderung lebih banyak belajar pada pola data mayoritas daripada yang minoritas, sehingga keputusan yang dihasilkan oleh classifier akan menjadi bias.

\section{Daftar Pustaka}

[1] BAPPEDA, "Data Koperasi dan UKM," Dataku, 2020. [Online]. Available: bappeda.jogjaprov.go.id/dataku/data_dasar?id_skpd=18.

[2] T. T. Maskoen and D. Purnama, "Area Under the Curve dan Akurasi Cystatin C untuk Diagnosis Acute Kidney Injury pada Pasien Politrauma," Maj. Kedokt. Bandung, vol. 50, no. 4, pp. 259-264, Dec. 2018. 
[3] S. Syarli and A. Muin, "Metode Naive Bayes Untuk Prediksi Kelulusan (Studi Kasus: Data Mahasiswa Baru Perguruan Tinggi)," J. Ilm. Ilmu Komput., vol. 2, no. 1, pp. 22-26, Apr. 2016.

[4] N. Y. Septian, "Data Mining Menggunakan Algoritma Naïve Bayes Untuk Klasifikasi Kelulusan Mahasiswa Universitas Dian Nuswantoro," J. Semant. 2013, pp. 1-11, 2009.

[5] S. Salmu and A. Solichin, "Prediksi Tingkat Kelulusan Mahasiswa Tepat Waktu Menggunakan Naïve Bayes : Studi Kasus UIN Syarif Hidayatullah Jakarta,” in Seminar Nasional Multidisiplin Ilmu (SENMI) 2017, 2017, no. April, pp. 701-709.

[6] S. Widaningsih, "Perbandingan Metode Data Mining untuk Prediksi Nilai dan Waktu Kelulusan Mahasiswa Prodi Teknik Informatika dengan Algoritma C4,5, Naïve Bayes, KNN dan SVM,” J. Tekno Insentif, vol. 13, no. 1, pp. 16-25, Apr. 2019.

[7] P. A. Lizsara, S. Oyama, and S. Wardani, "Implementasi Data Mining Menggunakan Metode Naïve Bayes Untuk Memprediksi Ketepatan Waktu Tingkat Kelulusan Mahasiswa (Study Kasus: Program Studi Informatika Universitas PGRI Yogyakarta)," Seri Pros. Semin. Nas. Din. Inform., vol. 4, no. 1, pp. 34-37, Apr. 2020.

[8] S. Rahmatullah, "Prediksi Tingkat Kelulusan Tepat Waktu dengan Metode Naïve Bayes dan KNearest Neighbor,” J. Inf. dan Komput., vol. 7, no. 1, pp. 7-16, Apr. 2019.

[9] P. S. C. Moonallika, K. Q. Fredlina, and I. B. K. Sudiatmika, "Penerapan Data Mining Untuk Memprediksi Kelulusan Mahasiswa Menggunakan Algoritma Naive Bayes Classifier (Studi Kasus STMIK Primakara)," J. Ilm. Komput., vol. 6, no. 1, pp. 47-56, Feb. 2020.

[10] L. A. Hunt, "Missing data imputation and its effect on the accuracy of classification," in Studies in Classification, Data Analysis, and Knowledge Organization, 2017, no. 195089, pp. 3-14.

[11] A. Fernández, S. García, M. Galar, R. C. Prati, B. Krawczyk, and F. Herrera, Learning from Imbalanced Data Sets. Springer International Publishing, 2018.

[12] A. Fernández, S. García, M. Galar, R. C. Prati, B. Krawczyk, and F. Herrera, "Imbalanced Classification with Multiple Classes," in Learning from Imbalanced Data Sets, Springer International Publishing, 2018, pp. 197-226.

[13] A. Fernández, S. García, M. Galar, R. C. Prati, B. Krawczyk, and F. Herrera, "Foundations on Imbalanced Classification," in Learning from Imbalanced Data Sets, Springer International Publishing, 2018, pp. 19-46.

[14] S. Fotouhi, S. Asadi, and M. W. Kattan, "A comprehensive data level analysis for cancer diagnosis on imbalanced data,” J. Biomed. Inform., vol. 90, Feb. 2019. 